\title{
THE DEFINITION OF CRIMINAL ORGANIZATION AND RELATED COURT PRACTICE IN TAX-FRAUD CRIMINAL CASES $^{1}$
}

\author{
VYMEDZENIE ZLOČINECKEJ ORGANIZÁCIE A \\ SÚVISIACA PRAX SÚDOV VO VECIACH DAŇOVÝCH \\ PODVODOV
}

\author{
Ferenc Santha \\ University of Miskolc, Faculty of Law \\ https://doi.org/10.33542/SIC2019-1-07
}

\begin{abstract}
Tax fraud - or more precisely - budget fraud is the most frequent type of crimes associated with the economic activity in Hungary. Criminal organization is one of the so-called joint perpetrations, in addition to the criminal conspiracy and group perpetration. Since over the past years, there are several budget fraud cases when the crimes were committed in a criminal organization, this paper outlines the characteristics of the crime of budget fraud and the definition and statutory elements of the criminal organization, and also shows the relationship between these legal intruments. Finally, I would like to shortly introduce a specific budget fraud case when the crime was committed in a criminal organization.
\end{abstract}

\begin{abstract}
ABSTRAKT
Daňový podvod - alebo presnejšie, rozpočtový podvod je jeden z najfrekvetovanejším trestným činom spojeným s ekonomickými aktivitami v Mad’arsku. Zločinecká organizácia je jedným z tzv. spoločných páchatel'ov, popri zločineckému sprisahaniu a skupinovému páchatel'stvu. Za posledné roky je možné identifikovat' niekol'ko prípadov rozpočtových podvodov, kedy trestné činy boli spáchané zločineckou organizáciou. Tento príspevok vymedzuje základné znaky trestného činu rozpočtového podvodu a definuje zákonné znaky zločineckej organizácie, ako aj poukazuje na vzt’ah medzi týmito právnymi inštrumentami. A napokon, poukazujem aj krátko na jeden prípad rozpočtového podvodu, kedy trestný čin bol spáchaný zločineckou organizáciou.
\end{abstract}

\section{INTRODUCTION - ECONOMIC CRIMES OR CRIMES ASSOCIATED WITH THE ECONOMIC ACTIVITY IN HUNGARIAN CRIMINAL CODE}

The term 'economic crimes' does not exist in the Hungarian Criminal Code (HCC), but it can be defined as follows: economic crime is a form of a criminal behaviour which is realised in the economic process or closely related to it, which given its nature and context (especially

\footnotetext{
This research was supported by the project nr. EFOP-3.6.2-16-2017-00007, titled Aspects on the development of intelligent, sustainable and inclusive society: social, technological, innovation networks in employment and digital economy. The project has been supported by the European Union, co-financed by the European Social Fund and the budget of Hungary.
} 
the modification of the commission) is suitable for breaching or endangering the fair operation and the legal order of the economy. ${ }^{2}$

There are totally twenty-eight crimes in five chapters in the HCC which can surely be considered as 'economic crimes'.

These five chapters are the following: (1) Chapter 38. Crimes Relating to Counterfeiting Currencies and Philatelic Forgeries, which contains - among others - the Counterfeiting Currency and the Cash-Substitute Payment Instrument Fraud; (2) Chapter 39. Crimes againts Public Finances, which contains e.g. the Budget Fraud; (3) Chapter 40. Money Laundering; (4) Chapter 41. Economic and Busines Related Crimes, which contains e.g. the Fraudulent Bankruptcy and the Concealment of Assets for Avoiding a Liability; (5) Chapter 42. Crimes againts Consumer Rights and Any Violation of Competition Laws, in which we can find e.g. the Marketing of Substandard Products, the Misleading Consumers or the Imitation of Competitors.

In addition to these crimes, the Hungarian legal literature and so do I uses the term 'crimes associated with the economic activity', which means, along with what I have mentioned, several serious offences if committed in the framework of an economic organization, like Fraud, Embezzlement, Economic Fraud, or Misappropriation of Funds.

It should be emphasized that the definition of economic crimes in criminology has a wider range than the criminal law's concept. It is realized in the economic process or closely related crime form to this process which violates or endangers the prudent management, fair and legal frames of economy. Among crimes against property the following crimes can be mentioned: embezzlement, fraudulence, misappropriation, and among the corruption crimes: bribery and influence peddler. ${ }^{3}$

In the first part of my paper, after the short introduction, I would like to outline the statutory definition and some characteristics of the crime of budget fraud. In the second, I would like to examine the features and elements of the definition of criminal organization in the light of the criminal court practice. Finally, the third part is devoted to introduce a specific budget fraud case when the crime was committed in a criminal organization.

\section{CRIME OF BUDGET FRAUD IN HUNGARIAN CRIMINAL LAW}

Crime of budget fraud exists in Hungarian criminal law since the 1st of January 2012, in the Chapter $39^{4}$ of the HCC, titled Crimes againts Public Finances. When decided to place into a separate chapter, the legislator has taken account of the fact that budget frauds are often but not exclusively committed by the participants of the economic life. ${ }^{5}$ Therefore, crime of budget fraud and the related criminal offences can rather be considered as the most important criminal acts of the financial criminal law (which is the part of the economic criminal law in a broader sense) ${ }^{6}$

TÓTH M: Gazdasági bünözés és büncselekmények. KJK-KERSZÖV Kft., 2002. 22. p.

KÖHALMI L - MEZEI K: The concept and typical forms of economic crime. Journal of Eastern-European Criminal Law, No.2/2015. 34. p.

4 Chapter 39 of the HCC contains the crime of budget fraud; fraud relating to social security, social and other welfare benefits; omission of oversight or supervisory responsibilities in connection with budget fraud; and conspiracy to commit excise violation.

5 TÓTH, M: A pénzügyi bűncselekmények. In: Magyar büntetőjog. Különös rész (szerk. Erdősy Emil - Földvári Jozsef Tóth Mihaly). Osiris Kiado, Budapest, 2007. 507. p.

6 JACSÓ, J: A költségvetési csalás. In: A negyedik magyar büntetőkódex régi és újabb vitakérdései (szerk. Hollán Miklós Barabás A. Tünde), MTA Társadalomtudományi Kutatóközpont - Országos Kriminológiai Intézet, Budapest, $2017,274$. p. Economic criminal law in Hungary is the sum total of legal regulations within and outside criminal law that define which of the actions threatening the economic order (that is, the orderly operation of the economy) are considered criminal acts, how the perpetrators of these are to be held responsible, what sanctions can be applied against them and how. See WEI, C: The Hungarian Economic Criminal Law in the New Hungarian Criminal Code. Büntetőjogi Szemle 2012/3. 3. p. 
The Article 396 of HCC, which contains the provisions relating to budget fraud, is a complex statutory definition which has been drafted in a manner which takes into account the following objectives:

- all fraud-related crimes which detrimental to the budget should be integrated in one criminal offence: a number of previously regulated crimes, e.g. tax-fraud, excise violation, illegal trafficking of excise goods, violation of the financial interest of the European Communities have terminated and the crime of budget fraud should be applied;

- the definition of the new offence was formulated in an extremely abstract manner in order to remove all the possible loopholes and possiblities of abuse. ${ }^{7}$ Accordingly, this offence is constituted if it is committed in connection with any budget payment obligation (e.g. taxes, customs, levies, fines), or with any funds deriving from the budget (including export subsidies and intervention aids);

- the aim was to put the national budget and the budgets or funds managed by or behalf of European Union at the centre of criminal law protection ${ }^{8}$ and to facilitate the proper legal classificiation for the users of the law, especially for the judges. The solution of the questions of plurality of offences became much simplier, since the legislator established a so-called statutory unity, namely it is not relevant whether the perpetrator causes financial loss to one or more budgets, or commits the crimes in connection with different taxes (e.g. VAT, corporate tax), or the criminal act is affected one or more tax declaration periods: in all the referred cases only one offence should be established and the amount of the financial losses should be added;

- With the criminal offence of budget fraud, the Hungarian legislator aims to protect not only the national budget, but also the budgets and/or funds managed by or on behalf of international organizations and budgets and/or funds managed by or on behalf of the European Union. ${ }^{9}$

There are three basic cases of the offence:

- the „classical” budget fraud (budget fraud in a narrower sense);

- the excise violation, which involves duty and tax evasion from excise products such as tobacco, alcohol and oils, and

- the so-called ,administrative” budget fraud, which means the breach of accounting or notification duties related to the funds driving from the budgets.

It is also deserving of mention the criminal liability of the heads of business regarding the crime of budget fraud. With respect to this crime, the Article 397 of the HCC contains the relevant provision, a separate offence named 'Omission of Supervisory or Controlling Duty in connection with Budget Fraud'. Under this Article, the leader of the business organization, or its member or employee entitled to control or supervision is punishable, if the member or employee fails to fulfil the duty of control or supervision, and thus makes it possible for the member or employee of the business organization to commit the budget fraud within the scope of the business organization's activities.

in the Hungarian criminal law. In: Current questions and european answers on the field of law and justice in Romania and Hungary (ed.: Christian Dumitru Mihes - Diana Cirmaciu), Editurii Pro Universitaria, 2016.

But now I only focus on the „classical” budget fraud. The statutory definition of the offence consists of three parts:

a) The first type of the offence can be committed if the perpetrator induces a person to hold or continue to hold a false belief, makes a false statement, or suppresses known facts (in

7 See the Ministerial Explanation of the Act LXIII of 2011 which modified the HCC and introduced the budget fraud into the Hungarian criminal law.

8 GULA J: A költségvetést károsító büncselekmények. In: GÖRGÉNYI-GULA-HORVÁTH-JACSÓ-LÉVAY-SÁNTHAVÁRADI: Magyar büntetőjog különös rész. Wolters Kluwer Kft., 2013. 604. p.

9 UDVARHELYI B.: The protection of the financial interests of the European Union in the Hungarian criminal law. In: Current questions and european answers on the field of law and justice in Romania and Hungary (ed.: Christian Dumitru Mihes - Diana Cirmaciu), Editurii Pro Universitaria, 2016. 207. p. 
connection with any budget payment obligation or with any funds deriving from the budget). The typical examples of the above mentioned criminal act is the illegal VAT refund or VAT deduction. Also included here are the so-called carousel frauds and fraud cases committed in connection with the activity of temporary work agencies, which will be discussed in the following.

b) The second can be realized if the perpetrator unlawfully claims any advantage made available in connection with budget payment obligations. This act is typically carried out in relation to tax- and customs benefits. One example in Hungarian court practice is the case, when a business organization claimed the corporate tax benefit for small and medium-sized companies despite the fact that it was not a small or medium-sized company. ${ }^{10}$

c) Finally, the third form of the crime is the use of funds deriving from the budget for purposes other than those authorized. For example, this was the case when the accused unlawfully claimed the fund financed jointly by the Phare Programme of the EU and the Hungarian state.

Budget fraud is a material offence, which contains not only the criminal act but also the harmful consequences caused by the perpetrator, namely the financial loss to one or more budgets. The HCC defines financial loss generally as the damage to one's property, including lost income. However, a special provison should also be applied in connection with budget fraud: ,any loss of revenue stemming from non-compliance with any budget payment obligation, as well as the claiming of funds from a budget unlawfully or the use of funds paid or payable from a budget for purposes other than those authorized." The larger the amount of the financial loss, the more serious is of the punishment ${ }^{11}$, but if the financial loss caused by the act is 100.000 HUF (around 300 Euro) or less, the case shall be treated as an administrative offence instead of a real crime. Additional aggravated cases of the budget fraud are when the crime is committed on a commercial scale or in a criminal conspiracy.

In this respect, it is important to note the provision related to commutation of the punishment. According to the Article 396(8), the penalty may be reduced without limitation if the perpetrator provides compensation for the financial loss caused by the budget fraud before the indictment is filed. The aim of this rule is to encourage the perpetrator to pay subsequent reparation. However, the formulation of the provision is problematic, as it shall not apply to the typical case of the budget fraud, when the offence is committed in a criminal conspiracy. It seems a better solution to regulate the self-report of the perpetrator together with the compensation of the financial loss as a ground of impunity. The self-report of the perpetrator (Selbstanzeige) is laid down as a ground of excuse in many foreign countries, e.g. in Germany or in Austria. ${ }^{12}$

\section{THE DEFINITION OF CRIMINAL ORGANIZATION}

Criminal organization is one of the so-called joint perpetrations, in addition to the criminal conspiracy and group perpetration. The common characteristic of joint perpetrations is that two or more persons are involved in the commission of the crime and imply a certain division of activities and a certain degree of organization. However, there are important differencies: criminal conspiracy and group perpetration have been existing for a long time in Hungarian criminal law and these forms are regulated as aggravated cases with a more serious punishment

10 MISKOLCZI, B: A költsegvetést karosító bűncselekmények. In: Új Btk.Kommentár (főszerk. POLT P). Nemzeti Közszolgálati és Tankönyv Kiadó, Budapest,2013. 27. p.

11 If the crime causes a financial loss between 100.001 and $500.000 \mathrm{HUF}$, it is punishable by imprisonment not exceeding two years. The penalty of imprisonment not exceeding three years if the budget fraud results in considerable financial loss (500.001-5.000.000 HUF); imprisonment between one to five years if it results substantial financial loss (5.000.00150.000.000 HUF); imprisonment between two to eight years if it results in particularly considerable financial loss (50.000.001-500.000.000 HUF), and imprisonment between five to ten years if it results particularly substantial financial loss (over 500.000.000 HUF).

12 JACSÓ J (2017) 291. p. 
of certain criminal offences (e. g. robbery committed in a group perpetration or drug trafficking committed in criminal conspiracy).

On the other hand, criminal organization has been incorporated into the HCC only in $1997^{13}$, with a view to stepping up the fight against serious organised crime. Perpetration within the framework of a criminal organization is not an aggravated case of a crime, but several serious legal consequences provided by the General Part of HCC shall be applied, e.g. the maximum imposable penalty is to be doubled (however, this punishment may not exceed twenty years); all assets obtained by the perpetrator during his involvement in a criminal organization have to be regarded as subject to confiscation until proven otherwise; the exclusion of the possibility of a suspended sentence of imprisonment or of release on parole, etc.

The HCC (Art 459(1) 1. defines the term of the criminal organization as follows: ,when a group of three or more persons collaborate in the long term to deliberately engage in an organized fashion in criminal acts, which are punishable with five years of imprisonment or more".

As the prosecutor bear the burden of proof, he/she is required to prove the elements of the criminal organization, which are as follows:

a) The HCC requires a minimum number of three members for a criminal organization and they may be criminally liable as a principal perpetrator or an instigator or an abettor, but a minimum one principal perpetrator is a necessary condition. It can happen that there is change in the composition of the members: such mobility is usually does not itself affect the existence of the organization and is irrelevant for the establishment of the criminal organization and its legal consequences. ${ }^{14}$

b) Criminal organization is a group established over a longer period of time: commission of only one or two crimes occasionally does not constitute criminal organization, the term of "longer period" concerns the relative stability of the structure of the organization. ${ }^{15}$ Though it is not possible to determine precisely, according to the court practice, a few months of operation can be considered as "longer period”, in particular where it is clear that the members of the organization intended to commit further crimes, additional to those already committed (e.g. when the perpetrators intended to use the large quantities of weapons acquired by illegal arms trafficking for the showdown of the rival gangs).

c) Criminal organization is a group of persons collaborating in an organized fashion, or, in other words, a group of persons operating in concert. The criminal organization means not only the collective action of persons but requires a kind of qualitative extra characteristic. The commission of crimes in an organized manner is not sufficient, this element assumes a higher level of coordination, division of tasks, planning and direction. According to the court practice, a number of facts make it possible to conclude that this condition is fulfilled, e.g.

- hierarchical relationships between the members,

- separation of the levels of activities (e.g. the level of decision-making, control and execution),

- system of command and control,

13 Act LXXIII of 1997 established and formulated the definition of the criminal organization. The commission of several criminal offences by a person being a member of a criminal organization was evaluated as an aggravated case of the offence. The wording was ' a criminal organization is a criminal conspiracy established to repeatedly commit criminal acts - based on a distribution of labour - for the purpose of gaining profits on a regular basis'. See in details: BALOGH A: The Definition of Criminal Organization and Consequences of Committing Crime in the Framework of a Criminal Organization under Hungarian Criminal Law, 2015 Law Series Annals W. U. Timisoara 14 (2015), 15-17. p. According to the modified definition in 1998 (Act LXXXVIII of 1998), 'criminal organization is a criminal conspiracy established to commit criminal acts on a regular basis for the purpose of enrichment, that is based on the distribution of labour, a hierarchy of subordinates and superiors and on active participation based on personal relationships'.

14 NÁNÁSI L: A szervezett bűnözés kérdései a magyar anyagi és eljárási büntetőjogban (Egy precedensügy tapasztalatai. Romániai Magyar Jogtudományi Közlöny, 2006/3. 46. p.

15 TÓTH M: Bünszövetség, bünszervezet. Complex Kiadó Kft., 2009, 129. p. 
- conspirative methods of the communication between the members, e.g. using special words and terms during the phone calls,

- coordinated action againts the authorities, e.g. in case of arrest of a member, the organization provide a defence lawyer and cover the costs. ${ }^{16}$

According to the court practice, it is not necessary a direct link between the members of the organization and it is irrelevant whether they know each other or not. ${ }^{17}$ The element of operating in concert may also be found, if the activities of the perpetrators are harmonized by one leader, even the knowledge about each other's activities is not possible to establish.

d) The purpose of the criminal organization is the commission of minimum two criminal offence that are punishable with five years of imprisonment or more. This does not mean that the perpetrator must know about the measures of punishment, but he/she must understand that the purpose of the criminal organization is to commit serious crimes. ${ }^{18}$

A criminal organization already comes to existence also in cases where the members have not yet committed such a crime. It is another question that the above mentioned serious legal consequences (e. g. the doubled maximum penalty) can only be applied if the members attempt to commit at least one criminal offence. A criminal organization can be organized for the commission of any criminal offence punishable with five years or more (no exhausted list of the relevant crimes) and the purpose to obtain a financial or other material benefit the that is not required (though this is a typical case). However, it remains unclear whether all the members should be involved in the commission of the crime (punishable with five years imprisonment or more), and if the answer is yes, then what kind of form of perpetration is relevant? ${ }^{19}$

Finally, it shoud be emphasized that the perpetrator must not only be aware of the objective elements of the criminal offence(s) committed in the criminal organitation but he/she also must know the above mentioned factual elements of criminal organization. ${ }^{20}$

The definition of the criminal organization is seemingly based on the term of the group perpetration. This solution might have some disadvantages since the condition of the group perpetration is the presence of three or more perpetrators at the place of the crime. This criterion cannot reasonably be applied in connection with the criminal organization because it is contrary to the nature and the characteristics of a criminal organization, especially to the division of labour. $^{21}$

\section{A BUDGET-FRAUD CASE COMMITTED IN A CRIMINAL ORGANIZATION - SHORT CONCLUSION}

Over the past years, there are several budget fraud cases in which criminal proceedings have been initiated againts temporary work agencies. The method applied by the perpetrators in the particular case at hand is to operate a company which pretend to deal with temporary agency work. This ,agency” seemingly lends its employees to companies which carry out genuine economic activity. However, the workers have been employed by the same companies previously and although the ,agency” became the new employer, the time, the place and the position of the work has not changed. The 'agency' fails to pay the social security and other releated contributions to the budget and issues fictional invoices for the temporary agency work which are placed into the accounting of the companies and used for the illegal VAT-deduction.

According to indictment, the criminal organization was established by six accused. The leader of the organization was the accused I who directed the activities of the members of the

\footnotetext{
16 TÓTH M (2009) 130-131. o.

17 Uniformity decision no. 4/2005 BJE rendered by the Hungarian Supreme Court.

18 BALOGH A (2015) 19-20. p.

19 GELLÉR B: A magyar büntetőjog tankönyve I. Általános tanok. Magyar Közlöny Lap- és Könyvkiadó, Budapest, 2008. 260. p.

20 Uniformity decision no. 4/2005 BJE rendered by the Hungarian Supreme Court.

21 NAGY F: A magyar büntetőjog általános része. Korona Kiadó, Budapest, 2004, 312. p.
} 
organitation and who was informed by the members of their criminal activities. He approved the transactions managed by the members and instructed them during the time of the contact between the criminal organization and the companies used the 'services' of the organization. He tried to avoid to come into direct contact with the activity of the criminal organization, and therefore he maintained relations with the other members of the organization and the companies by the accused II. The latter person forwarded the instructions of the leader to the other members of the organizations, and directed the activity of the members and the temporary work agency. Accused III, IV and V were involved in the operation of the temporary work agency and they kept in contact with the companies in connection with the fictional temporary agency work and invoicing services.

On that basis, the prosecutor proposed for the court in the indictment to declare that the accused committed the budget fraud in a criminal organitation and requested the imposition of a serious imprisonment with the exclusion of the possibility of a conditional release.

It is clear from the file of the case that the temporary work agency failed to pay the social security and other releated contributions to the budget and the invoices were fictional, since the agency did not carry on any real temporary agency work. More than three members were involved in the activity of the criminal organization, and the operation of the organization lasted for more than one year. The members have all known each other and, according to the confidental informations gathered by the police by phone-tapping, they communicated and consulted on the duties and tasks in connection of the operation of the temporary work agency on a regular basis. On that basis, the element of 'operation in concert' can also be established. They committed thirty-two separate crimes of budget fraud punishable with more than five years of imprisonment, since the 'services' of the temporary work agency were used by the same number of companies. In light of the aforementioned, it is not difficult to predict that defending aganins the accusations will be a major challenge for the accused and their defence lawyers.

Crime of budget fraud has particular importance since these crimes are the most common in the area of crimes associated with the economic activity. Over the last decade Hungary (and other countries of the European Union) have seen an increase in budget fraud cases (in Hungary 1555 crimes in 2012, 2178 crimes in 2013, 2284 in 2014, 2154 in 2015), ${ }^{22}$ and many of these crimes have been committed in a criminal organization causing hundreds of billions financial loss to the national budget. Therefore, effective fight againts budget fraud and similar financial crimes is one of the greatest challenges facing the Hungarian law enforcement authorities over the next years.

\section{KEYWORDS}

crime of budget fraud, tax-fraud, criminal organization, economic crimes, crimes associated with the economic activity

\section{KLUÚČOVÉ SLOVÁ}

Trestný čin rozpočtového podvodu, daňový podvod, zločinecká organizcáia, ekonomické trestné činy, trestné činy spojené s hospodárskou aktivitou

\section{BIBLIOGRAPHY}

1. BALOGH A: The Definition of Criminal Organization and Consequences of Committing Crime in the Framework of a Criminal Organization under Hungarian Criminal Law, 2015 Law Series Annals W. U. Timisoara 14 (2015)

\footnotetext{
${ }^{22}$ Source: Egységes Nyomozóhatósági és Ügyészségi Bűnügyi Statisztika (ENYÜBS).
} 
2. GELLÉR B: A magyar büntetöjog tankönyve I. Általános tanok. Magyar Közlöny Lap- és Könyvkiadó, Budapest, 2008.

3. GULA J: A költségvetést károsító büncselekmények. In: GÖRGÉNYI-GULAHORVÁTH-JACSÓ-LÉVAY-SÁNTHA-VÁRADI: Magyar büntetőjog különös rész. Wolters Kluwer Kft., 2013.

4. JACSÓ J: A költségvetési csalás. In: A negyedik magyar büntetőkódex régi és újabb vitakérdései (szerk. Hollán Miklós - Barabás A. Tünde), MTA Társadalomtudományi Kutatóközpont - Országos Kriminológiai Intézet, Budapest, 2017,

5. KÖHALMI L - MEZEI K: The concept and typical forms of economic crime. Journal of Eastern-European Criminal Law, No.2/2015.

6. MISKOLCZI B: A költsegvetést karosító büncselekmények. In: Új Btk.Kommentár (föszerk. Polt Péter). Nemzeti Közszolgálati és Tankönyv Kiadó, Budapest,2013. 27. p.

7. NÁNÁSI L: A szervezett bünözés kérdései a magyar anyagi és eljárási büntetőjogban (Egy precedensügy tapasztalatai. Romániai Magyar Jogtudományi Közlöny, 2006/3.

8. NAGY F: A magyar büntetőjog általános része. Korona Kiadó, Budapest, 2004.

9. TÓTH M: Gazdasági bünözés és büncselekmények. KJK-KERSZÖV Kft., 2002.

10. TÓTH M: „A pénzügyi büncselekmények” In: Magyar büntetőjog. Különös rész (szerk. Erdősy Emil - Földvári Jozsef - Tóth Mihaly). Osiris Kiado, Budapest, 2007.

11. TÓTH M: Bünszövetség, bünszervezet. Complex Kiadó Kft., 2009.

12. UDVARHELYI B: The protection of the financial interests of the European Union in the Hungarian criminal law. In: Current questions and european answers on the field of law and justice in Romania and Hungary (ed.: Christian Dumitru Mihes - Diana Cirmaciu), Editurii Pro Universitaria, 2016.

\section{CONTACT DETAILS OF AUTHOR}

Dr. Sántha Ferenc

associate professor

University of Miskolc, Faculty of Law

3515 Miskolc-Egyetemváros, Hungary

santhaferenc@hotmail.com 